\title{
O MÉTODO MÉZIĖRES OU A REVOLUÇÃO NA GINÁSTICA ORTOPÉDICA: O MANIFESTO ANTI-DESPORTIVO OU A NOVA METODOLOGIA DE TREINO
}

AUTOR

Luís Coelho'

Fisioterapeuta mézièrista, professor de Pilates e investigador na área das raquialgias

O MÉTODO MÉZIĖRES OU A REVOLUČ̃̃̃ NA GINÁSTICA ORTOPÉDICA: O MANIFESTO ANTI-DESPORTIVO OU A NOVA METODOLOGIA DE TREINO 4(2): 21-39

\section{INTRODUCÃO}

Em termos ditos 'músculo-esqueléticos', pode considerar-se que o conhecimento dos métodos de fisioterapia que consubstanciam teorética e pragmaticamente a "intervenção postural" constitui uma base de sapiência fundamental para a boa prestação do profissional de "educação física" e o profissional de saúde especializado.

Dentro das abordagens de natureza fisioterapêutica, diversos métodos de tratamento podem ser utilizados, sendo que os mesmos podem ser divididos em duas grandes categorias: tratamentos analíticos (centrados fundamentalmente nos sintomas do doente e realizados sobretudo a nível local] e tratamentos holísticos (centrados na causa dos sintomas do doente e realizados a nível global].

Os tratamentos holísticos aparecem substanciados na forma de métodos mais ou menos globais que tendem a ver a pessoa como um todo inextricável. No contexto do presente artigo, são considerados tratamentos ditos holísticos todos aqueles que centram a sua acção num ponto de análise da estrutura corporal do sujeito, vista como um todo. Falamos, nomeadamente, na postura corporal e, portanto, nos métodos de intervenção postural (e mais precisamente de Reeducação posturaß.

Neste contexto, surgem as dificuldades de definição operacional do conceito de Postura e de Reeducação Postural que tentaremos ultrapassar num primeiro momento do texto. Compreenderemos muito precisamente que o conceito de Reeducação Postural adoptado no documento deriva de todos os métodos que se iniciaram com a revolução introduzida por Françoise Mézières (1909-1991), portanto, métodos de origem e ambiente francófono lque iremos caracterizar pormenorizadamente à frente no artigo), cuja história remonta à segunda metade do século XX. Estes métodos serão designados por mézièristas, sendo que têm em comum o facto de se basearem todos naquela que podemos denominar de teoria das Cadeias musculares. Uma explanação dos conceitos iniciará o percurso teorético a que se cinge 0 artigo. De seguida, iremos analisar resumidamente aquilo que entendemos por métodos clássicos de intervenção postural, sendo que só depois de desenvolvermos estes pré-requisitos teóricos é que iremos percorrer todo um percurso histórico relativo ao método Mézières e outros de natureza "mézièrista". No fim do nosso texto, iremos expor o conjunto das conclusões devidas, relacionadas com o percurso teórico coadjuvado, sendo de sublinhar o agrupado de "implicações" que o campo teorético e pragmático dos métodos de intervenção "mézièrista" possui sobre a prática desportiva em geral.

\section{Explanando os conceitos básicos} Diversos investigadores têm dado luz a múltiplos métodos de "intervenção postural" sem que uma definição conceptual de "postura" tenha sido aprioristicamente relevada; daí que muitas das confusões metodológicas e pragmáticas dos vários métodos de "correcção postural" nunca tenham sido adequadamente resolvidas. Por exemplo, 
tanto no método Pilates quanto no Stretching fala-se de "postura", mas em ambos os métodos realizam-se conjuntos de metodologias físicas dissemelhantes, sendo que uma se centra mais na força do centro do corpo e a outra se centra mais na flexibilidade. Iremos tentar ordenar todos estes diversos campos semânticos e idiomáticos.

Comecemos pela caracterização do termo "postura". Este possui um significado original de "posição, atitude ou hábitos posturais"1. Por "postura" podemos entender, em termos práticos, "a posição optimizada, mantida com característica automática e expontânea, de um organismo em perfeita harmonia com a força gravitacional e predisposto a passar do estado de repouso ao estado de movimento"; funcionalmente, pode ser considerada como "o conjunto de relações existentes entre o organismo como um todo, as várias partes do corpo e o ambiente que o cerca"; substancialmente, porém, vai de acordo com "um complexo sistema de muitos moldes, no qual intervém, além do carácter biomecânico, um conjunto de variáveis".

Enquanto "posição corpórea", "postura" pode referir-se tanto à posição relativa a um tempo determinado, tendo como exemplo o conjunto das curvaturas vertebrais funcionais, como à posição relativa a uma estrutura determinada, admitindo agora como exemplo o conjunto estruturado lou, como veremos mais tarde, virtualmente estruturado] das curvaturas vertebrais (ditas anatómicas).

Efectivamente, quando falamos de "postura" podemos estar a referir-nos a um "fenómeno" consubstanciado por diferentes perspectivas/ /dimensões e níveis. Tribastone ${ }^{1}$ refere-se a planos, comparando os mecanismos de controlo postural com os mecanismos de controlo do movimento (a postura pode ser, inclusive, definida como um conjunto incomensurável de múltiplos e microscópicos movimentos - definindo-se esta como uma perspectiva 'dinâmica' da postura). Temos, portanto, o plano anatómico, relativo à organização racional da actividade perceptivo-motora, alcançada a partir de movimentos, e com a normalização do conjunto das cadeias cinéticas, actuando na reequilibração das tensões miofasciais e das cadeias articulares; o plano neuromotor, relativo às sensações proprioceptivas e às variáveis aferentes de controlo postural; e o plano psicomotor, relativo à organização do esquema corporal, alcançada a partir da percepção consciente e do conhecimento do próprio corpo, das suas modalidades de funcionamento e da sua organização espacio-temporal.

No respeitante aos mecanismos de regulação da postura, estamos a entrar num terreno essencialmente "neurológico" que é composto por um conjunto de quatro níveis" 1) centros superiores, que compreendem o cérebro, o cerebelo e o tronco cerebral; a esses chegam as informações provenientes principalmente dos fusos neuromusculares, dos mecano-receptores articulares, dos órgãos tendinosos de Golgi, e também da retina, da pele e do vestíbulo; 2) interneurónios, motoneurónios alfa e gama, contidos na espinal medula; 3) músculo e todos os factores que influenciam a resposta contráctil (referimo-nos principalmente a músculos posturais, ou seja, músculos de controlo essencialmente inconsciente); e 4] fusos neuromusculares, órgãos tendinosos de Golgi, vestíbulo e receptores sensoriais.
Diferentes métodos de "intervenção postural" agem sobre uma ou mais partes dos referidos níveis de controlo postural. Daí que um processo de "reeducação postural" nunca possa limitar-se só à dimensão neurológica ou só à dimensão muscular per si. Por outro lado, os diferentes níveis de controlo postural, pelo facto de estarem intimamente relacionados, influenciam-se mutuamente, sendo de esperar que a intervenção num nível acarrete mudanças na totalidade dos níveis de controlo.

Por exemplo, o paradigma de Bricot ${ }^{2}$ refere-se sobretudo ao nível neurológico, sendo que a sua intervenção [postural) acarreta modificações a nível proprioceptivo, regendo-se esta pela administração de palmilhas de reprogramação postural, pela modulação do receptor ocular e/ou pela intervenção ao nível do receptor dento-oclusal. Apesar de um tanto ultrapassado, o modelo de Bricot constitui ainda plataforma obrigatória do estudo da posturologia [esta entendida num sentido lato]. Neste artigo, iremos reger-nos sempre pelo seguinte conjunto de dimensões posturais: neurológica (já referida), funcional e estrutural. A relação entre as dimensões funcional e estrutural da "postura" pode ser considerada como complexa, sendo que, para o paradigma das "cadeias musculares" não há algo referente a verdadeira estrutura, pois esta é, virtualmente, modificável pelos diversos métodos de reeducação postural.

Neste artigo, iremos tratar de diferentes maneiras os conceitos de "ginástica correctiva postural" e de "reeducação postural". A história da primeira é bastante mais longa do que a história da segunda. A primeira rege-se sobretudo pela dimensão funcional da "postura", 
enquanto que a segunda "mexe" supostamente com as estruturas. A primeira, em conjunto com a dimensão neurológica de "postura", passa por diferentes métodos de "ginástica", desde o método clássico sueco de Per Henrik Ling (1766-1839), centrado em princípios tradicionais de movimento e alongamento céleres, até ao moderno método Pilates, centrado nos contemporâneos estudos referentes à estabilidade lombo-pélvica ${ }^{3}$, passando pela cinesiterapia vertebral, pela "ginástica respiratória"1, por diferentes abordagens físicas de tratamento da escoliose [consultar Tribastone $^{1}$ ], a psicomotricidade ${ }^{4} \mathrm{e}$ o relaxamento ${ }^{5}$. A segunda rege-se pela aquela que designamos de "teoria das cadeias musculares", a qual é desenvolvida iniciaticamente pelo paradigma mézièrista.

Importa aqui referir que para muitos profissionais de saúde o método Pilates constitui um verdadeiro método de "reeducação postural". Não o consideramos neste artigo, pois, não obstante o conjunto inexprimível dos resultados na dor lombar obtidos com o treino de estabilidade dinâmica do tronco (para mais pormenores, consultar Richardson et $\mathrm{al}^{3}$ ), o método Pilates não ultrapassa as dimensões neurológica e funcional mais efémeras de "postura". Somente os métodos que designamos como "reeducação postural", centrados na "metodologia das cadeias musculares" influenciam certos aspectos mais "permanentes" da postura, aqueles relativos à "estrutura" ou morfologia.

Tentemos, agora, definir o conceito de postura "normal".

Para Bricot ${ }^{2}$, a postura normal significa a ausência de forças contrárias e a presença de relações harmoniosas entre as diferentes componentes esqueléticas. 0 resultado será a inexistência de dor.
Já que pretendemos referenciar o paradigma Mézières, vamos referir o que é a postura perfeita para o método com o mesmo nome. A Madame Mézières costumava referir-se às formas das obras de arte renascentista enquanto "formas de dimensões perfeitas". O trabalho em Mézières constitui um esforço de retorno à "morfologia perfeita", conhecida como a bela forma. As proporções da bela forma correspondem ao número de ouro (em relação a $\sqrt{5}+/-1 / 2$ ] para o qual todos deveríamos tender.

A "bela forma" de Mézières caracteriza-se por: vendo de face, as clavículas, os ombros, os mamilos, os espaços braquiotorácicos devem ser simétricos e estar ao mesmo nível; os contornos laterais do tórax devem ser rectilíneos e divergir desde as cristas ilíacas até à prega da axila; de costas, a nuca deve ser longa e cheia, os ombros, as ancas e as omoplatas devem ser simétricas e não devem apresentar qualquer relevo, o feixe inferior do trapézio deve aparecer (numa pessoa não obesa] até à décima segunda vértebra dorsal; em posição de flexão do tronco à frente, com a cabeça pendente, a coluna dorsal deve apresentar-se na linha das cabeças do astrágalo e não recuar para trás dos calcanhares (recurvatum), e a coluna deve ser visivel naquele que muitos denominam de "sinal da roda da bicicleta"; de perfil, a ponta do mamilo deve ser o ponto mais avançado, abaixo do qual o contorno anterior do tórax e do abdómen deve ser rectilíneo até ao púbis, o contorno das costas deve ser visível, o braço separa o 1/3 posterior do tórax dos 2/3 anteriores.

Todas as alterações relativas à postura dita "correcta" correspondem a paramorfismos, se as alte- rações são temporárias e reversiveis, e a dismorfismos, se as alterações se consideram fundamentalmente irreversíveis ${ }^{1}$ (claro que esta classificação não preenche os quesitos conceptuais do método Mézières, já que para o mesmo a linha teórica que separa as tais "dismorfias" dos referidos "paramorfismos" é assaz espúria).

Para Bricot ${ }^{2}$, mais de $90 \%$ dos indivíduos apresentam um desequilíbrio postural. Para o autor, os desequilíbrios posturais comportam planos: o plano de alinhamento escapular e das nádegas, com aumento das curvaturas; o plano escapular posterior; o plano escapular anterior com dorso plano; e os planos alinhados com diminuição das curvaturas.

É de reter também a classificação postural de Kendall, dentro das quais são paradigmáticas as kyphosis-lordosis posture, sway back posture e flat back posture.

A avaliação postural pode ser meramente observacional, mas pode também fazer uso de instrumentos e metodologias complexas ${ }^{1}$. A mais utilizada pelos clínicos é indubitavelmente sustida pela observação naturalística em real time. É a partir dessa observação, e não esquecendo nunca a "imagem", algo quimérica, fornecida pela bela forma, que o terapeuta mézièrista irá conduzir a sua acção, sempre com vista à aquisição da morfologia "perfeita".

Sem desprimor das definições apresentadas, diria que tanto as classificações existentes de 'postura' como as enunciações definidoras da sua "normalidade" vs. "anormalidade" caem no erro de considerar a "postura" como um arquétipo concreto, objectivo e bem definido. A meu ver, a "postura" está para o corpo como a "personalidade" está 
para a mente. Assim como é difícil definir a normalidade/anormalidade do funcionamento personalístico, segundo um ponto de vista psicologista, também é difícil definir os critérios de normalidade da "postura corporal". A "postura" é, tal como a personalidade, essencialmente uma idiossincrasia, um "corpus" definidor de um conjunto intrincado de factores psiconeurológicos, psico-emocionais, músculo-esqueléticos e neuromusculares, variáveis, muitas vezes radicalmente, de sujeito para sujeito. Portanto, a tentativa de classificar a postura "normal" vs. "anormal" é, apesar de útil no ponto de vista nosológico, dispensável segundo o ponto de vista dinâmico e "morfoanalítico".

\section{O método Mézières e a revolução na ginástica ortopédica}

A compreensão dos princípios do método Mézières implica o entendimento da postura sobretudo como o resultado funcional do equilíbrio "estático" entre as cadeias musculares. Mas o que são as cadeias musculares? E de que maneira as mesmas contribuem para desenhar a forma do corpo, para moldar a sua estrutura? Vamos tentar responder a estas questões no contexto da explicação da história do método Mézières.

A história do método em questão releva de determinados acontecimentos e observações que são do bom conhecimento do terapeuta mézièrista.

A própria Mézières (figura 1) conta na sua obra "L’homéopathie francaise" (traduzindo): "Quando numa magnífica manhã de primavera de 1947, nós vimos entrar no nosso consultório uma paciente apresentando uma soberba 'cifose', nós estávamos bem longe de pressentir que a nossa profissão e o destino de toda uma legião de doenças iam ser mudadas. Tratava-se de um sujeito longilíneo, muito alto e magro. Um colete de couro e ferro não havia conseguido parar, como esperado, a progressão da doença"'. Nesta época, a ginástica postural clássica era realizada com base nas leis fisiológicas que aceiram o papel do fortalecimento muscular. E foi esse mesmo tipo de trabaIho que foi feito inicialmente com a doente. Mézières refere: "Nós tentámos, naturalmente, os exercícios de 'endireitamento' e o trabalho dos músculos dorsais com vista a fortalecer os extensores do tronco, mas a rigidez era tal que nada era possível realizar. Deitando, então, a nossa doente, no chão, em decúbito dorsal, nós realizámos a flexão dos ombros e vimos, para nosso espanto, produzir-se uma enorme lordose lombar. Para não acrescentar um mal à cifose já presente, nós realizámos a báscula posterior da bacia e, para nosso novo espanto, vimos a hiperlordose lombar esquivar-se e deslocar-se para a nuca"s (figura 2).

Depois de repetida várias vezes a experiência, Mézières e os colegas acabaram por admitir uma verdade que viria a ser anunciada como uma nova lei: que "todo o encurtamento parcial da musculatura posterior leva a um encurtamento de todo o conjunto desta musculatura", o que corresponde à noção de cadeia muscular, onde "toda a modificação de comprimento no sentido do alongamento ou no sentido do encurtamento de parte da musculatura tem repercussão sobre todo o conjunto".

Francoise Mézières acrescenta: "Tanto que como o alongamento da musculatura lombar se traduzia pelo encurtamento da curvatura cervical, a lei é que o alongamento de um qualquer músculo posterior leva ao encurtamento do conjunto de toda a musculatura posterior"6. É o que costumamos chamar de compensação.

"Então, para esta paciente, nenhum músculo posterior era demasiadamente fraco ou longo, nem mesmo os da região cifosada; pelo contrário, todos estavam curtos, rígidos e fortes demais. $\mathbf{O}$ sujeito não era de forma alguma esmagado pela acção da gravidade (noção clássica), mas sim achatado pela sua própria força, a dos seus músculos dorsais. Era preciso, ao invés de fortalecer esta musculatura, descontraíla, alongando de uma ponta à outra da coluna vertebral, como se se tratasse de uma lordose"

Actualmente sabemos que a "cadeia posterior", identificada pela primeira vez por meio das observações de Mézières, inclui um comportamento dinâmico, o qual integra um conjunto muito avultado de estruturas musculares, como o diafragma e, até mesmo, a musculatura anterior. Esse comportamento dinâmico integra um conjunto de inúmeras compensações, geradas por mecanismos protectores, sendo que estes são devidos ao denominado reflexo anti-álgico à priori. Veremos, igualmente, mais à frente que a noção de "cadeia muscular" [e também dos seus constituintes] diferenciou-se um tanto com a prossecução teorética dos diversos métodos de linha "mézièrista".

Entrámos, efectivamente, num conjunto de noções variadas que inicialmente Mézières não dominava completamente. A fisioterapeuta resumia, efectivamente, as suas observações em duas partes: (1) a musculatura posterior comporta-se como um só músculo e (2) ela é sempre forte de mais, curta de 
mais, potente de mais. E, para os proponentes de Mézières, o princípio preliminar de que todas as deformações têm origem num encurtamento da musculatura posterior manteve-se incólume até à data.

Deve, também, ser acrescentado que a própria Françoise Mézières terá cedo percebido que existia uma sinergia importante entre a musculatura posterior e o diafragma e os músculos rotadores internos dos membros [cadeia muscular ântero-interna].

Assim sendo, a desmontagem dos princípios far-se-ia na forma de um "tripé de intervenção", com vista à harmonização muscular na forma da morfologia perfeita ou bela forma: deslordose, expiração e desrotação (figura 3 e figura 4).

Da observação iniciática de Mézières $^{6}$ do paciente cifótico, referida atrás (conhecida como o "princípio

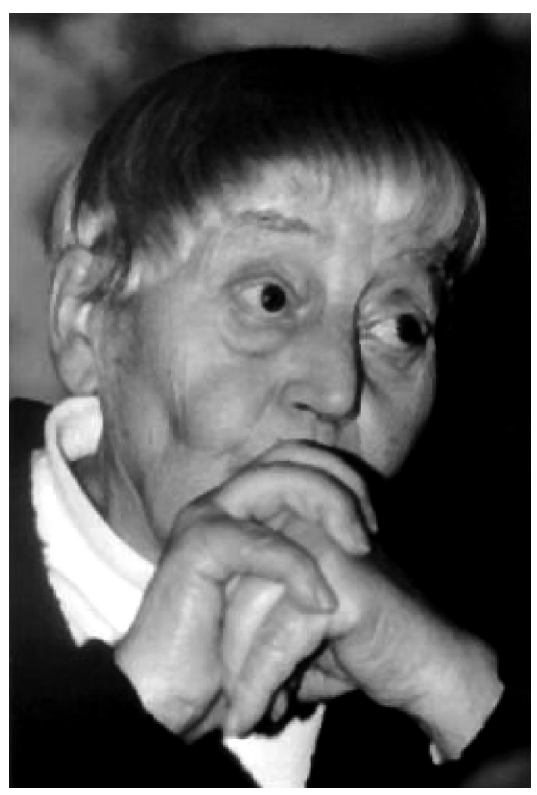

FIGURA1

Françoise Mézières (1909-1991). de observação"), Mézières tira diversas conclusões (mantemos, agora, o original francês): (1) "ll n'est que des lordoses»: a cifose (e a escoliose] não é possível sem uma acentuação das lordoses e é vista como a sua consequência. A lordose constitui a origem de todas as deformações do ráquis e dos membros. Para além disso, ela ocorre em todos os movimentos de extensão e nos movimentos de grande amplitude dos membros. (2) "La lordose est mobile et coulisse sur le corps tel un anneau sur une tringle à rideau.» (3) "Les membres sont solidaires du tronc et le creux poplité constitue, en dehors du rachis, une troisième concavité postérieure liée aux lordoses rachidiennes." (4) "Tout est compensation lordotique» (5) "La lordose s'accompagne toujours de la rotation interne des membres.» (6) «La morphologie thoracique est conditionnée par certains mouvements de la tête et des membres supérieurs.» (7) "La lordose coexiste toujours avec le blocage du diaphragme en inspiration.»

As conclusões de Mézières levaram a que a autora enunciasse oficialmente um conjunto de seis leis na sua obra "Originalité de la Méthode Mézières" (1984) (7): PRIMEIRA LEI: "Les nombreux muscles postérieurs se comportent comme un seul et même muscle [Une chaîne musculaire se définira comme étant un ensemble de muscles polyarticulaires et de même direction, qui se succèdent en s'enjambant comme les tuiles d'u toit); SEgUNDA LEI: Les muscles des chaînes sont trop toniques et trop courts (il n'y a donc rien qu'il faille renforcer); TerceIRA LEI: Toute action localisée, aussi bien élongation que raccourcissement, provoque instantanément le raccourcissement de l'ensemble

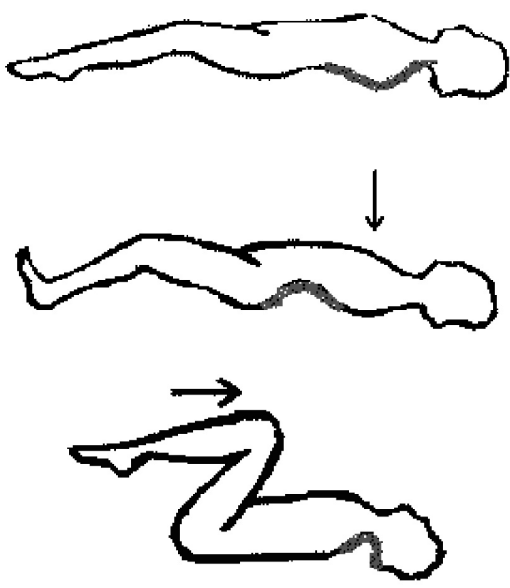

FIGURA?

Lógica das compensações musculares.

du système; QuARTA LEI: Toute opposition à ce raccourcissement provoque instantanément des latérofléxions et des rotations du rachis et des membres (lógica das compensações); QuINTA LEI: La rotation des membres due à l'hypertonie des chaînes s'effectue toujours en dedans; SEXTA LEI: Toute élongation, détorsion, douleur, tout effort implique instantanément le blocage respiratoire en inspiration.

0 esquema 1, apresentado seguidamente, representa o "anel Mézières", o qual resume os princípios referidos anteriormente.

Do esquema apresentado, podemos dizer que, para Mézières, todas as deformações ocorriam a partir de uma ou mais lordoses, sendo que esta[s] estaria[m] associada[s] à rotação dos membros (relacionada com o encurtamento do psoas e outros músculos sinergistas] e ao bloqueio diafragmático (associado ao encurtamento do diafragma e dos diversos músculos suspensores das vísceras, incluindo muscu- 


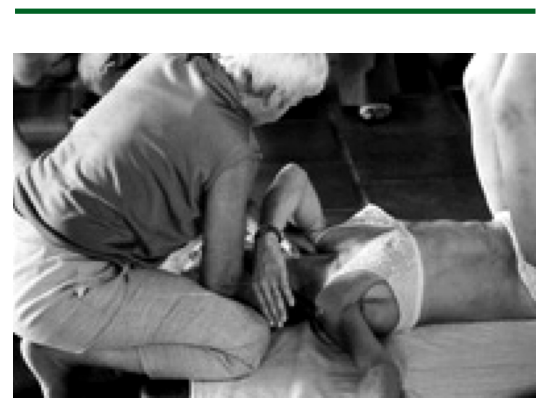

FIGURA3

Françoise Mézières tratando uma doente. É visível a aplicação do princípio da deslordose.

latura sinergista com inserção superior na coluna cervical). 0 tratamento segundo Mézières corresponderia precisamente a toda a acção de alongamento muscular global e prolongado com vista à deslordose, desrotação e desbloqueio diafragmático los princípios fundamentais de trabalho de Mézières, assim como os princípios da "revolução na ginástica ortopédica" viriam a ser formulados iniciaticamente na sua obra "Révolution en Gymnastique Orthopédique"8) 0 tratamento mézièrista consiste precisamente num conjunto de posturas que possibilitam o tratamento iniciático de um "bloco superior" da "cadeia posterior" (constituído pela cabeça, coluna cervical, cintura escapular e membros superiores, e coluna dorsal até T7) e, logo de seguida, ao tratamento do "bloco inferior" da "cadeia posterior" (coluna de T7 até ao cóccix, cintura pélvica e membros inferiores) (figura 5).

A cadeia muscular posterior era vista como a estrutura principal a trabalhar. 0 conceito de "cadeia muscular" não aparece inicialmente na obra de Mézières. As "cadeias musculares" vão sendo "formuladas" ao longo da obra da autora: a cadeia braquial, a grande cadeia posterior e a cadeia ântero-interna são postas em evidência por Mézières, enquanto que a cadeia anterior do pescoço é posta em evidência por Nisand (futuro criador da "Reconstrução Postural"] e aceite, mais tarde, por Mézières (ver figuras 6 e 7 com imagens clássicas, respectivamente das cadeias musculares posterior e anterior].

A obra e método de trabalho de Mézières parte de um postulado patogénico: "La forme conditionne la fonction et la douleur est à envisager comme un signal d'alarme d'une déformation qui aurait atteint

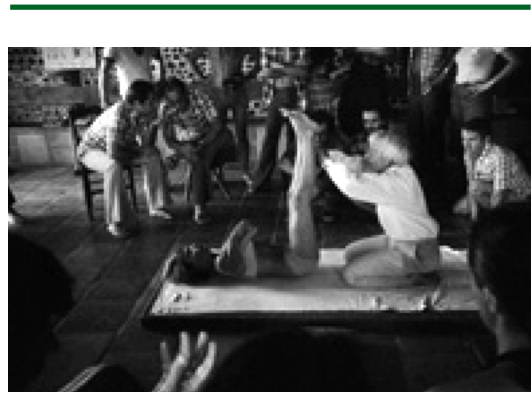

FIGURA4

Françoise Mézières deslordosando e desrodando uma doente.

son seuil d'acceptabilité.» 0 princípio terapêutico da Globalidade é proposto bastante cedo pela autora e consistia no já referido "tripé de tratamento". As posturas de alongamento deveriam ser realizadas com "alongamento global de todas as cadeias musculares envolvidas", através de "contracção isométrica excêntrica".

Veremos, de seguida, que diversos foram os métodos desenvolvidos a partir do original de Mézières, sendo que tanto a noção de "cadeia muscular" como os princípios de tratamento sofreram grandes alteracões, por parte de diversos autores.

- Deformações congénitas
ou primitivas
- Patologias
- Trauma
- Dores
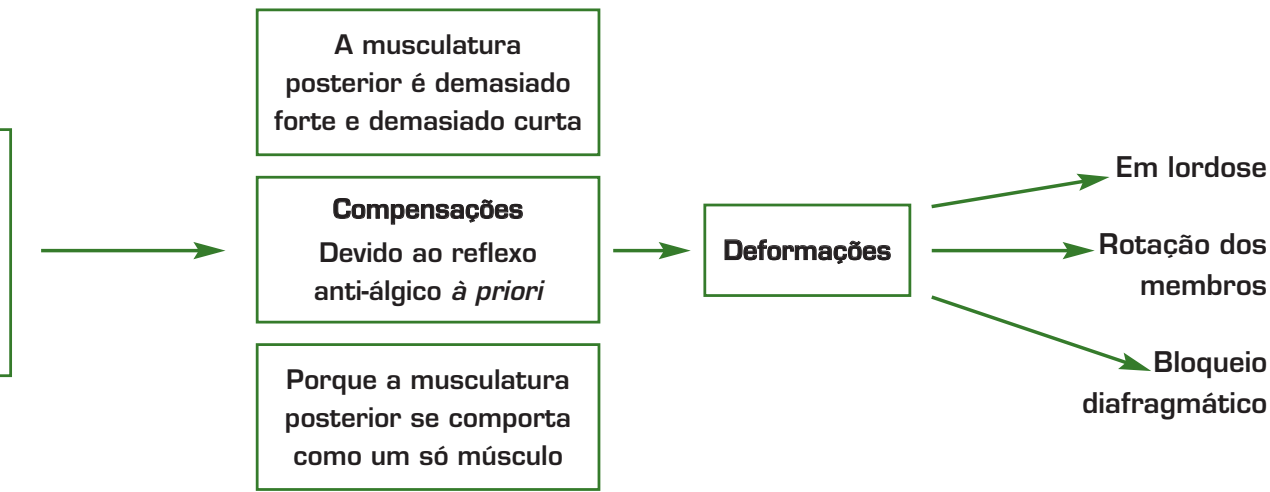


\section{As técnicas ditas "mézièristas"}

As técnicas ditas "mézièristas" constituem todas aquelas que advêm directa ou indirectamente do trabalho de Françoise Mézières.

Mézières ensinou a sua arte desde os finais dos anos 50 até à sua morte em 1991. Perto do fim da sua vida, ela estimou o número de terapeutas com o seu curso como sendo de cerca de mil e quinhentos. Esta cifra é meramente aproximativa e não pode deixar de ser moderada pelo facto de os seus cursos não possuírem programa, avaliação de conhecimentos ou registo das presenças dos formandos. Ou seja, não eram necessárias muitas "condições" e/ou critérios para que um terapeuta fosse considerado "mézièrista".

A proliferação de escolas paralelas tornou-se inevitável, isto desde os anos 60. Em 1990, Mézières declarou: «Je m'indigne en voyant une multitude de kinésithérapeutes prétendre améliorer, voir enseigner ma méthode, alors qu'il y a fort peu de praticiens qui l'aient réellement assimilée ${ }^{9}$. 0 fenómeno da proliferação de escolas (e do método em si) amplificou-se consideravelmente após a publicação do livro de Thérèse Bertherat" ${ }^{10}$ "Le corps a ses raisons" (1976), traduzido para português para o desapropriado título "Dê saúde ao seu corpo: a saúde pela antiginástica" (Europa-América). A obra de Bertherat (ver fotografia em figura 8) era toda ela de "inspiração" mézièrista, sendo que incluía um capítulo inteiro dedicado ao método de Mézières. Foi esta mesma obra que permitiu a criação da fama relativa ao método, aliás um tipo de "(re)conhecimento" que a própria Mézières não pretendia. Depois da obra de Bertherat ter conhecido um sucesso mundial de vendas, Mézières recebeu o prémio da "Legião de
Honra", e passou a ser ouvida na rádio e vista na televisão. A sua fama aumentou de forma descontrolada, algo que a própria Mézières não pretendia. Tanto ela como os fisioterapeutas mézièristas pretendiam manter o método dentro das lides clínicas e académicas, sendo que não gostaram que o método passasse a fazer parte da "opinião pública" (aliás, ainda muitos terapeutas mantêm esta tendência para manter determinada "arte de intervenção" no "segredo dos Deuses", dificultando, muitas vezes, a assunção de um conjunto muito avultado de vantagens relativamente ao conhecimento de "novos" campos de conhecimento e terapêutica]. Quanto às obras de Bertherat, estas foram feitas para o grande público, possuindo o erro da simplificação abusiva. Porém, é de realçar a capacidade que Bertherat teve para explicar o método a todos os que não possuíam formação especializada. Para além disso, a autora teve, mais do que qualquer outro, a capacidade para compreender as verdadeiras implicações que o método Mézières possui para o mundo do desporto em geral. Em todas as suas obras, e principalmente em "Le repaire du tigre" ${ }^{\text {"13, }}$ Thérèse Bertherat conseguiu traduzir, com grande engenho, o conjunto dos erros e "deformações" que os métodos gímnicos modernos - e a maioria dos desportos de carácter assimétrico - alimentam. Aquilo que para Bertherat foi apelidado de "antiginástica", e que, na actualidade, poderia ser apelidado de anti-fitness, consiste precisamente no acalentar da ideia - contra-intuitiva mas científica - de que o treino de força muscular, apanágio das práticas desportivas contemporâneas - poderá resultar num excesso mio-fascial com consequências reumatológicas deletérias no longo prazo.

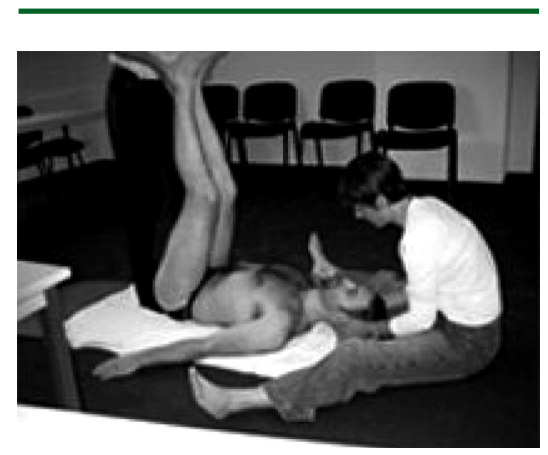

FIGURA5 Postura de trabalho com o método Mézières.
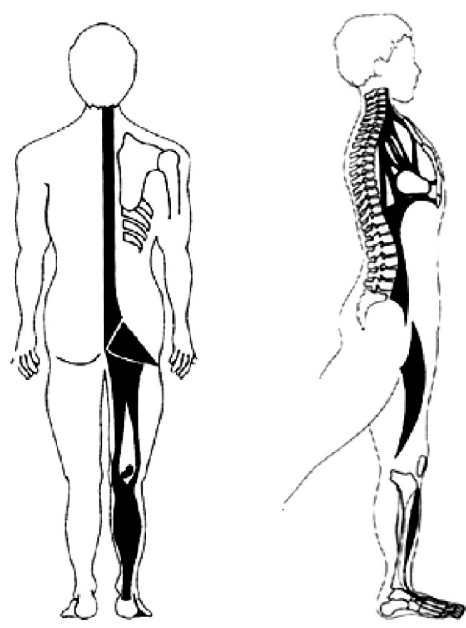

FIGURA6 E FIGURA7 Imagens clássicas dos conteúdos principais das cadeias musculares anterior e posterior.

Regressando à questão da proliferação de escolas, o que aconteceu inicialmente, e fortemente após a publicação da obra de Bertherat ${ }^{10}$, é que, visto que o nome "Mézières" estava fortemente inflaccionado, todos os autores que introduziram ideias interessantes no método recusavam-se a abandonar a apelidação "Mézières". Tudo isto levou a que Mézières ${ }^{7}$ acusasse os diversos autores de adulterarem o seu método e de utilizarem o seu nome como um viático. 
Por volta dos anos 80, Françoise Mézières fez proteger o seu nome através do Institut National de la Propriété Industrielle, o que obrigou os autores referidos a utilizarem outras denominações para apelidarem os seus "métodos".

No final, alguns anos depois de Mézières ter registado o seu método, muitos outros métodos do tipo "mézièrista" surgiram: (a) vários métodos que se reclamam como sendo independentes do método Mézières, apesar da evidência demonstrar que são métodos dependentes de Mézières e pouco diferentes teorética e pragmaticamente - do original. É o caso do método de Ph-E Souchard (um antigo assistente de Mézières, que, inclusive, ensinou e escreveu sobre o método], a Reeducação Postural Global (RPG); (b) as técnicas de antigos alunos de Mézières, ditas "método Mézières", mas que, no fundo, apresentam diferenças significativas relativamente ao método original. É o caso dos métodos ensinados pela Association des mézièristes d'Europe, pela Association Mézièriste Internationale de Kinésithérapie (AMIK) ou pela Association des Mézièristes du Nord. 0 método ensinado por estas associações já não é completamente congruente com o método original, como é advogado pelas mesmas. É o resultado de uma provavelmente lógica - evolução relativamente ao original; (c) técnicas que se reclamam como sendo de origem "mézièrista", mas que não escondem o facto de apresentarem "evoluções" relativamente ao original - tanto no plano teórico como no plano prático - evoluções que justificam a mudança de apelidação do método. É o caso do método das "Cadeias musculares e articulares" de Godelieve Denys-Struyf (uma importante retratista e escritora sobre o método Mé-

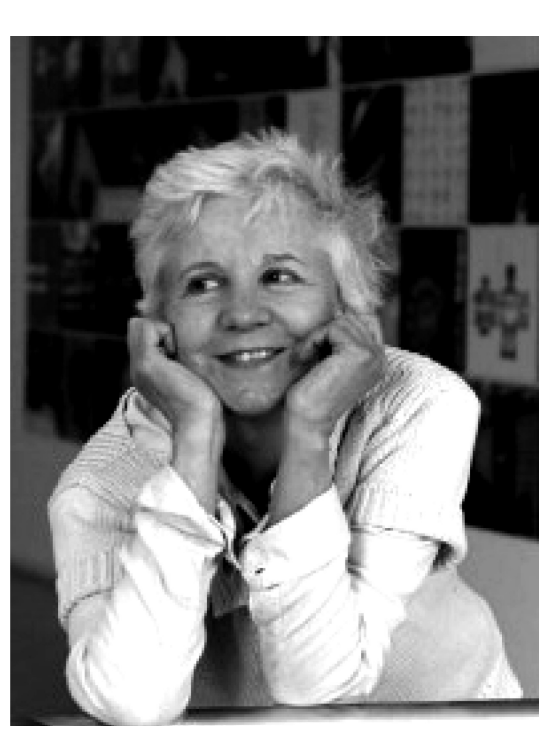

FIGURA8

Thérèse Bertherat.

zières), o método das "Cadeias musculares" de Leopold Busquet e a "Reconstrução Postural" de Nisand.

Digam o que disserem certos autores, todas estas escolas de fisioterapia possuem um "tronco comum", nomeadamente no método Mézières. Todas estas escolas podem, num sentido de "senso comum", ser apelidadas de "Reeducação Postural". Mas, devemos ter em atenção que o facto de existirem tantos outros métodos ligados à "reeducação da postura", como o método de Ida Rolf (rolfing) e associados (ex. "Trilhos anatómicos" de Myers], a técnica de Alexander, diversos métodos de relaxamento lcomo o "relaxamento muscular progressivo" de Jacobson e a técnica de Gerda Alexander], o treino de alongamento/stretching analítico [desde os princípios mais básicos de Per Henrik Ling), métodos como o Yoga e o Pilates (para além de muitas outras "invenções de marketing" mais modernas e menos holísticas], métodos mais ligados à dança, artes marciais (como o Tai-chi) e à expressão corporal/psicodrama/psicomotricidade, assim como métodos clássicos de tratamento da escoliose (método Schroth, método de Rudolf Klapp, método do Instituto Ortopédico Pini, método em cifose, método do psoas, método Gimnasium, o estruturalismo psicomotor, a reeducação proprioceptiva neuromuscular, a ginástica proprioceptiva e as técnicas de desequilíbrio) e os métodos da linha de Bernard Bricot (estes últimos já citados no início deste artigo], levam-nos a apelidar os métodos do "nosso artigo" como métodos de Reeducação Postural do tipo mézièrista. Todos estes partilham de dados conceptuais e práticos comuns ao método de Francooise Mézières.

Não se pretende, no entanto, deixar de realçar a importância de todos os métodos anteriormente citados. Muitos deles partem de princípios parecidos com certas "evoluções" relativas aos métodos mézièristas. Por exemplo, o rolfing trabalha o alongamento da massagem mio-fascial e é também esse o sentido do trabalho básico de Mézières, mas as metodologias práticas são completamente diferentes. A abordagem dos "Trilhos anatómicos" refere a existência de diversos "trilhos miofasciais", estes muito parecidos com as "cadeias musculares" de Busquet. E podíamos também comparar os diversos métodos de tratamento "proprioceptivo" da escoliose com os princípios de tratamento segundo a Reconstrução Postural de Nisand. E todos estes princípios de "inibição tónica" fazem lembrar os princípios neurofisiológicos de métodos de fisioterapia de "reabilitação neurológica” como o conceito de Bobath. 
E podiamos continuar eternamente a referir as parecenças entre os métodos, as quais podem, pelo menos em parte, ser explicadas pelas diferentes epistemis (M. Foucault) ou paradigmas (T. Kuhn) envolvidos numa lógica de similitude metodológica muitas vezes não assumida.

Voltando aos métodos do tipo mézièrista, já falámos da "antiginástica" de Bertherat. Mais do que um método (de trabalho grupal), é sobretudo um conceito. Um conceito relacionado com as implicações pouco percebidas - que os princípios mézièristas possuem para toda a "ginástica ortopédica".

Referimos também a Reeducação Postural Global de Ph-E Souchard. Este é provavelmente o método mais conhecido de todos. Muita coisa pode ser dita sobre o mesmo. E é claro que não é minha intenção constituir um resumo dos princípios do método; muito pela razão de que a maioria desses princípios, supostamente "descobertos" por Souchard, são princípios do método Mézières. Convido qualquer um a ler a obra de Souchard "Le champs clos - Bases de la Rééducation Posturale Globale"14 e a comparar os princípios do RPG com os princípios preliminares do método Mézières. É de lamentar que Souchard raramente refira a "mãe intelectual" do seu método, ainda mais porque o mesmo ensinou o método durante dez anos e escreveu sobre o mesmo. Não é criticável que Souchard tenha criado o seu próprio método. Ainda mais porque as suas posturas de trabalho lo seu método inclui oito posturas de alongamento] são claramente inovadoras. Portanto, apesar de as posturas do RPG não acrescentarem nada em termos metodológicos ao método Mézières, são bastante imaginativas, inovadoras e eficazes (ver posturas em figura 9).
Em termos teoréticos, Souchard vai dar mais atenção à[s] cadeia[s] anterior[s] do que Mézières; por exemplo, se para Mézières não há cifose sem lordose, para Souchard a cifose poderá constituir-se como uma entidade autónoma relativamente à lordose, com cadeias anteriores envolvidas em independência da cadeia muscular posterior. Para Souchard, há dois grandes conjuntos de "retracções" globais: posterior e anterior. As posturas de trabalho variam segundo as alterações existentes. Se analisarmos bem essas "posturas" veremos que algumas são iguais às posturas de Mézières, mas esteticamente mais belas e "politicamente" mais correctas; por exemplo, na postura "sentada" é mantida a curvatura lombar neutra, enquanto que essa curvatura tende a ser "deslordosada" no método Mézières (ver exemplos nas figuras 10 a 15). Talvez Souchard tivesse em conta as novas linhas de estudos "funcionais" que privilegiam a "utilização da coluna neutra". Aí, o autor talvez tivesse esquecido a máxima de Mézières "a saúde é o resultado da forma perfeita", pois, segundo a filosofia dos métodos vigentes, a forma prevalece sobre a função.

Para além do que fica dito, Souchard vai ter em conta a existência de cadeias musculares um pouco diferentes das do método original. Mas aí, ele não inova tanto quanto outros autores.

Aliás, a maioria dos autores "neo-mézièristas” (designação - nova que me ocorre neste momento], vai possuir uma noção de "bloco" e de "cadeia muscular" muito diferente da original. Dissemos, anteriormente, que o tratamento segundo Mézières incluía primariamente o bloco superior da cadeia posterior e só depois o bloco inferior. Ora, tanto o método de Souchard como o método de Busquet tentam dar uma ênfase de maior globalidade aos tais "blocos", trabalhando os dois "blocos" ao mesmo tempo, na medida do possível. Aliás, enquanto o tratamento segundo Mézières é feito num colchão, o tratamento segundo Souchard acaba por ser feito - individualmente - numa mesa própria, a qual permite colocar em tensão todas as cadeias musculares simultaneamente (principalmente quando utilizado o sistema de polias].

Resta dizer que, sendo o método mais conhecido, é a obra de Souchard que tem permitido expor muitas bases da "teoria mézièrista" ou "teoria das cadeias musculares". O autor publicou cerca de duas dezenas de obras, muitas delas com mais imagens que texto, e todas elas com uma certa tendência para ser recalcitrantes. Algumas são fundamentais, como a já citada "Le champs clos" e também a recente obra "Les scolioses - Traitement kinésithérapique et orthopédique" ${ }^{\text {15. }}$. Outras advêm da necessidade de criar um método mais adaptado à realidade desportiva como o "Le stretching global actif" ${ }^{\prime 16}$ (o Stretching Global Activo constitui um método grupal baseado igualmente em posturas de alongamento e princípios ditos "mézièristas"; foi feito a pensar sobretudo nas necessidades dos desportistas]. As suas obras foram traduzidas para o português do Brasil e podem ser encontradas nas livrarias especializadas. Em certos países, como o Brasil, o método de Souchard é considerado muitas vezes como original, sendo que é este que acaba por ser vítima de plágios e de tantos e tantos "formadores" a ensiná-lo. Neste mesmo país em particular, o ensino do método de Souchard atingiu proporções de merchandising avassaladoras. 


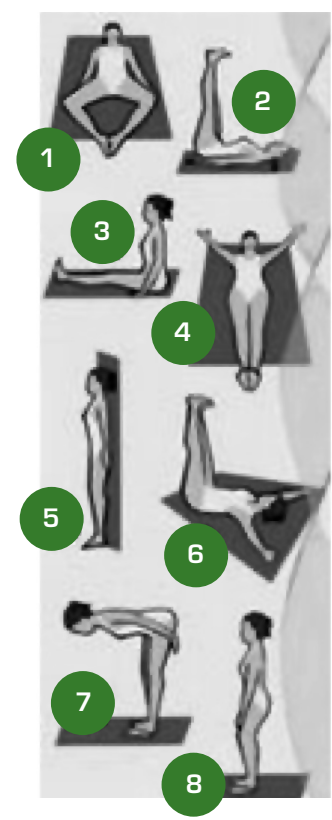

FIGURA9 Posturas do RPG.

1. rã no chão com fechamento dos braços; 2. rã no ar com fechamento dos braços;

3. postura sentada; 4. rã no chão com abertura dos braços; 5. postura de pé contra a parede; 6. rã no ar com abertura dos braços; 7. postura "bailarina"; 8. postura de pé.

Importa, ainda, dizer que a noção de "cadeia muscular" para Souchard acrescenta um pouco a Mézières, no sentido em que Souchard valoriza a diferenciação entre musculatura fásica (cadeias musculares dinâmicas] e musculatura tónica (cadeias musculares estáticas). E é o próprio Souchard que expõe em várias das suas obras os objectivos/ /princípios da Reeducação Postural [Global): [1ำ "Só as posturas activas em alongamento podem devolver aos músculos hipertónicos, rígidos e dolorosos, a sua força, o seu comprimento e a sua flexibilidade"; [2ำ "É necessário alongar os músculos da estática e os músculos suspensores, encurtando-se os músculos da dinâmica"; e [ $3^{\circ}$ ]
"Só as posturas de estiramento progressivo cada vez mais globais permitem alongar todos os músculos rígidos, assim como reencontrar a retracção de origem". Françoise Mézières não valorizava tanto a questão do "fortalecimento dos músculos fásicos" (aliás, tanto ela quanto Bertherat argumentavam que a força da musculatura fásica/ /anterior fluiria após ter sido inibido o tónus da musculatura tónica/ /posterior].

Sublinhemos, igualmente, os princípios de alongamento do Stretching Global Activo, os quais, segundo Souchard $^{16}$, distinguem o alongamento global do alongamento analítico: [1] "Os músculos existem na forma de cadeias musculares, princípio que irá implicar que o alongamento realizado seja tão global quanto a natureza da cadeia a alongar". (2) "Cada músculo tem diversas fisiologias, ou seja, cada músculo realiza diversas acções musculares, o que implica que seja necessário alongar um músculo em todas as suas acções simultaneamente". (3) "O alongamento dos músculos obedece à mesma fórmula física que os materiais viscosos e elásticos, ou seja, a fluagem muscular (que é a capacidade de alongamento permanente de um músculo] está dependente do produto da força de alongamento pelo tempo de alongamento, divididos ao coeficiente de elasticidade". Ora, visto que quanto maior a força mais doloroso é o alongamento, o alongamento deve depender portanto de um tempo mínimo, que é, no caso do alongamento global, muito superior ao que classicamente tem sido utilizado. Para além disso, como o aquecimento (seja na forma de exercício, seja na forma de calor local) aumenta o coeficiente de elasticidade, este fará com que o alongamento permanente seja menor, o que nos leva a afirmar que todo o alongamento deverá ser realizado a frio, antes da realização de qualquer exercício. (4) "Os nossos alongamentos serão sempre activos, ou seja, o alongamento em SGA deverá ser realizado por meio do trabalho activo e excêntrico da musculatura a alongar". (5) "A respiração é fundamental". Importa afirmar que o diafragma, em conjunto com outros músculos acessórios da inspiração, constitui uma cadeia muscular lordosante, sinérgica de todas as outras cadeias de músculos estáticos e posturais. Como tal, o alongamento só é globalmente possivel se for acompanhado do relaxamento/alongamento do diafragma. Por isso, todos os alongamentos devem ser realizados em expiração máxima.

Mais uma vez é notória a parecença dos "princípios do SGA" com os princípios básicos de Mézières. Importa, contudo, dar ênfase à questão do "quando" do alongamento. Para os diversos métodos mézièristas - e não só o RPG/SGA - o alongamento deve ser tão global quanto possível. E deve ser feito "a frio"; ou seja, ao contrário de tudo o que vem sendo dito e redito pelos "académicos" da "educação física" e do "fitness", o alongamento muscular deverá ser realizado antes do exercício e só nessa altura ele poderá ser verdadeiramente eficaz. A partir destes princípios, eu próprio tenho desmistificado a ideia de que o alongamento a frio é mais perigoso que o alongamento a quente, e que o mesmo deve ser feito de manhã e o mais global e progressivamente possível. Portanto, o alongamento deve ser a frio, global, mantido por longos períodos de tempo e levado progressivamente ao longo da amplitude articular. 
Em matéria de métodos "neo-mézièristas", é preciso entender que o método Mézières propriamente dito é, provavelmente, o mais passivo de todos. Todos os outros tendem para as posturas "activas". Voltando à questão das "cadeias musculares", importa referir que, se Souchard refere a existência de cadeias dinâmicas, então Busquet vai dizer que somente existe uma cadeia estática: a grande cadeia estática posterior. Todas as outras cadeias musculares são sobretudo de natureza dinâmica.

A obra de Busquet é bastante prolixa. Inicialmente, a sua única obra traduzida para português, nomeadamente a "A pubalgia"17, constitui uma importante referência dentro da linha de Mézières. Mas é estranho que Busquet praticamente nem sequer refira o nome de Mézières em praticamente toda a sua obra ${ }^{17,18}$.

De espantar está a linha de cadeias "neuromeníngeas" e "viscerais" em que Busquet vai colocar realce. A sua obra possui uma grandeza de conhecimento anatómico que qualquer outro mézièrista não possui. Num ponto de vista dos métodos "neo-mézièristas" é aquele que, segundo uma linha "orto-reumatológica” possui a maior completude. Neste ponto, é preciso referir que, se utilizássemos um critério de categorização dos métodos "neomézièristas" diferente do utilizado atrás, poderia dizer que há, sobretudo, métodos de linha mézièrista de natureza ortopédica (RPG e "Cadeias Musculares"], de natureza psicossomática ["Cadeias musculares e articulares" de Godelieve Denys-Struyf e "morfoanálise" de Peyrot] e métodos de natureza neurológica ["Reconstrução Postural"]. Apresento, agora, esta nova categorização, pois os métodos de Godelieve Denys-Struyf ${ }^{19}$ e de Peyrot
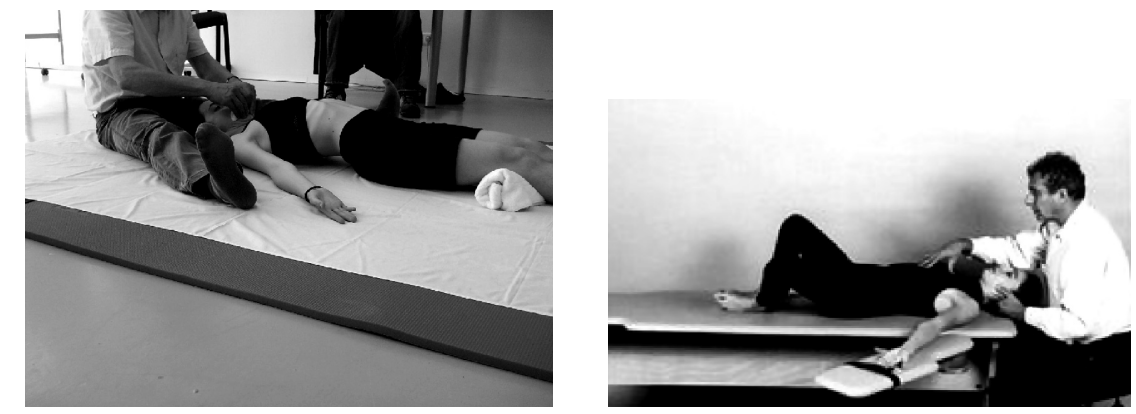

FIGURA10 E FIGURA11 Postura de Mézières (à esquerda) e a "correspondente" 'rã no chão' do RPG de Souchard (à direita).
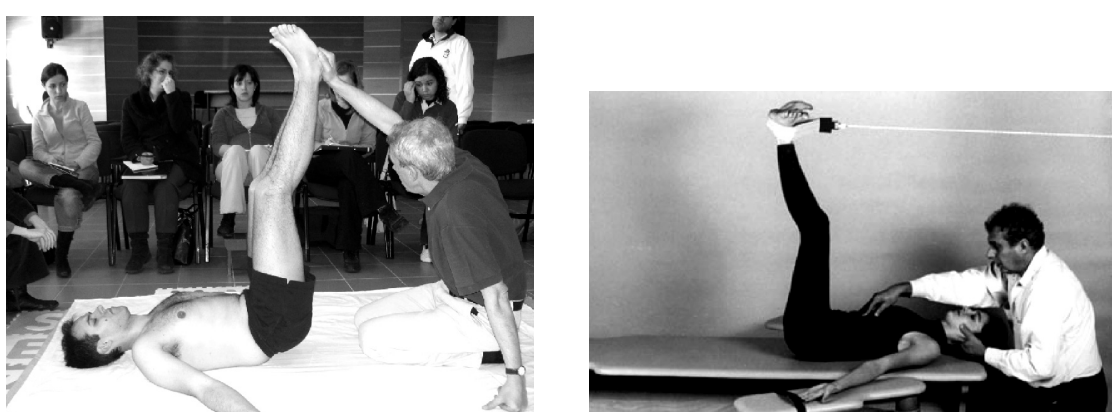

FIGURA12 E FIGURA13 Postura de Mézières e a "correspondente" 'rã no ar' do RPG de Souchard.
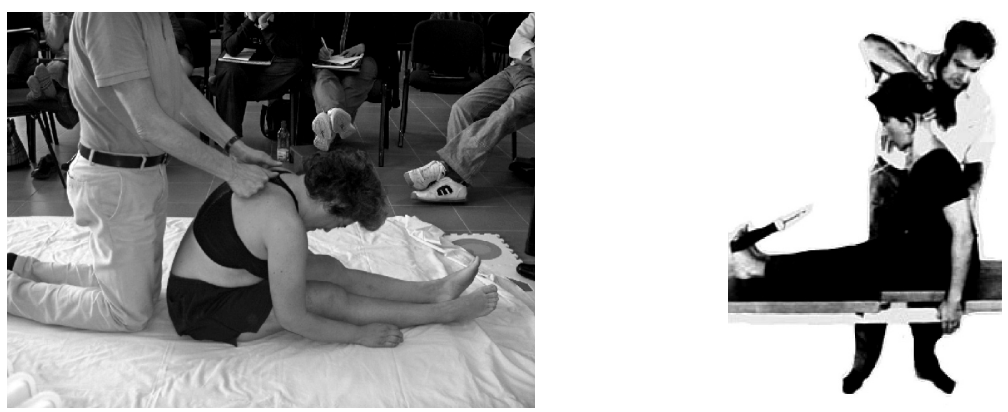

FIGURA14 E FIGURA15 Postura de Mézières e a "correspondente" 'rã sentada' do RPG de Souchard. 
(impossivel encontrar qualquer referência sobre este método] são de tal forma "diferentes" que só com muito esforço podemos considerá-los como métodos da linha da postura e/ou da motricidade humana. Esses métodos dão importância ao ser humano na sua totalidade psíquica e somática, e relacionam, de forma ímpar, a postura com os estados psicológicos (e vice-versa). Por exemplo, Godelieve Denys-Struyf, grande retratista de posturas, delineou a existência de cinco tipos de posturas, as quais se refeririam a cinco tipos diferentes de personalidade. É dela a frase "a estrutura governa a função e submete o psiquismo". A sua concepção de postura enquanto entidade psicossomática holística é fundamental à compreensão integral do ser humano. A sua "visão" releva de uma orientação mais psicologista do método Mézières; e leva-nos a entender até que ponto o conceito de Mézières (talvez seja mais correcto começar a utilizar este termo ao invés de "método Mézières"] é abrangente e tende para uma visão globalista do ser humano, visão aliás, também posta em evidência por Thérèse Bertherat - mais próxima das abordagens psico-corporais e psicomotricistas do que da actividade desportiva tida no seu frio "fisicalismo" quase anti-humano. Em matéria de métodos neo-mézièristas, o mais desconhecido de todos é, indubitavelmente, a Reconstrução Postural ${ }^{20,28}$, o que é bastante injusto, pois este é simultaneamente o mais fiel e o mais evoluído dos métodos pós-Mézières. É, como já dissemos, o mais fiel dos métodos, pois é aquele que mais respeita as bases teoréticas do método original; é, também, o mais científico dos métodos, pois, estando ligado à Universidade Louis Pasteur - Strasbourg, é aquele que mais respeita os critérios de uma necessária cientificidade; é também o método com os princípios mais inteligentes, pois foi o único que finalmente - compreendeu a "postura" enquanto entidade primacialmente neurológica. Ora, era preciso ter surgido este método em 1992 para finalmente percebermos - os poucos que sabem sequer da existência dele - que a postura não é talvez tanto o resultado de uma maior ou menor flexibilidade mio-fascial; se calhar, a postura depende, mais do que da elasticidade dos músculos, do seu tónus le jamais podemos esquecer que é através das variações de tónus que o sistema nervoso comunica com o sistema muscular].

A Reconstrução Postural difere do método Mézières em diversos aspectos, nomeadamente: (a) Enquanto Mézières se referia à existência de três cadeias musculares posturais la grande cadeia posterior, a cadeia ântero-interna diafragma e psoas - e a cadeia braquial), Nisand acrescenta e descreve pormenorizadamente uma nova cadeia muscular - a cadeia anterior do pescoço. (b) Nisand propõe uma nova interpretação da lógica das compensações corporais, salientando a importância de um conjunto de respostas neurológicas aquando do movimento (respostas evocadas) e o contributo dos centros neurológicos centrais para o surgimento das deformidades. Assim sendo, o tratamento passa não só pelo alongamento global das cadeias musculares (Mézières), mas também pelo trabalho de consciencialização corporal com base na estimulação neuro-sensorial (ou seja, na modificação do padrão de excitabilidade muscular das cadeias posturais], de modo a que os alongamentos possuam um efeito de neuroplasticidade adaptativa eficaz e não só um efeito de modi- ficabilidade temporária do tónus. (c) $O$ método da Reconstrução Postural propõe uma outra forma de interpretar o aparecimento de dor. A dor não tem origem na própria deformidade, mas sim na incapacidade que a estrutura hipertónica (rígida) tem de se deformar. A partir destas diferenças, o método de tratamento por Mézières por meio do estiramento em "contracção isométrica excêntrica" transforma-se num meio de tratamento por "solicitação activa induzida", ou seja, da postura trabalhada passivamente passa-se para um trabalho de carácter mais activo, mediante a facilitação de padrões de postura por meio de "pontos-chave" là semelhanca do papel dos mesmos "pontos-chave de controlo" do método Bobath de tratamento das disfunções neurológicas], partes do corpo que são sujeitas a movimentos de grande amplitude com o objectivo de induzir ou solicitar determinado padrão postural. As posturas em Reconstrução Postural são obtidas, portanto, a partir de pontos periféricos precisos, e são mantidas não por tempos necessariamente muito prolongados (Mézières), mas até ao ponto em que se verifique a normalização tónica. $\mathbf{O}$ agravamento da dismorfia é, ao contrário do que ocorre com o método Mézières, uma condição obrigatória para se obter a postura normal, é um ponto de passagem para a obtenção de um padrão postural "correcto". Diferenças metodológicas levam a diferentes técnicas, sendo que muitas das manobras mézièristas foram modificadas ou suprimidas: o mézièrista tende a evitar as compensações, enquanto que o "reconstrutor" tende a lidar com todas as posturas que possam ser efectivas no sentido de se obter uma inibição do padrão; o mézièris- 
ta identifica a dismorfia como algo "anormal", enquanto que o reconstrutor identifica a dismorfia como um ponto de passagem para a obtenção de um padrão postural vantajoso; o mézièrista tende a encontrar uma postura correctiva e a mantê-la o máximo de tempo possivel, enquanto que o reconstrutor tende a manter a "postura" só até que exista exaustão e extinção da resposta evocada (normalização tónica); as autoposturas são impensáveis na Reconstrução Postural (o que levanta uma série de questões relativamente ao trabalho de Reeducação postural em grupo], pois o próprio sujeito não consegue educar as suas próprias reacções tónicas correctivas; os proponentes da Reconstrução Postural não falam de "correcção morfológica" como os mézièristas, mas sim de "restauração morfológica", a qual tem por base não o alongamento mio-fascial correctivo mas sim o alongamento com vista à normalização de padrões de activação tónica das cadeias musculares.

Com todas estas inovações, o modelo de Nisand (porque é de um "modelo" que efectivamente se trata) constitui o mais inovador de todos os métodos de Reeducação Postural. É, provavelmente, o mais neurológico dos métodos e também o mais contra-intuitivo dos mesmos. Infelizmente, de todos os métodos, este é o único que carece de uma atitude de "comercialização" e de exploração para além da Universidade Louis Pasteur. Ou seja, é um método condenado à reclusão teorética. 0 que não pode deixar de se considerar como antitético. As implicações que este - e todos os outros métodos - possuem para a "dinâmica desportiva" e do axioma "exercício é saúde" são muitas e carecem de uma análise.

\section{As implicações da Reeducação Postural do tipo "mézièrista" para a prática desportiva}

Pretende servir este capítulo do nosso artigo de veículo de tomada de conclusões, para além das necessárias e intransponíveis reflexões relativas às implicações teoréticas e/ou pragmáticas (para o mundo do desporto] dos métodos anteriormente tratados.

Começaria por dizer que, dentro do conjunto dos métodos neo-mézièristas, há aqueles que seguem uma linha mais comercial de divulgação e aqueles que seguem uma linha mais conservadora de desenvolvimento. Em particular, métodos como a "antiginástica" de Bertherat e a "Reeducação Postural Global" auferem de uma fama a nível mundial, a qual tem permitido criar um número incomensurável de cursos e formações com preços simplesmente indescritíveis. Para além disso, tanto a "antiginástica" quanto o "Stretching Global Activo", filho do RPG, tornaram-se métodos de utilização grupal e massificada, a qual, não querendo diminuir a sua importância, não possui o mesmo grau de eficácia que os métodos verdadeiramente individuais.

Diria que todos os métodos neo-mézièristas possuem a robustez e a vitalidade de uma metodologia inovadora, que não deixou de possuir, principalmente no mundo francófono, a capacidade de criar uma verdadeira "revolução na ginástica ortopédica". Por motivos de coerência histórica, de parcimónia científica e de pureza metodológica, diria que é devido ao método Mézières o seu necessário e inalienável reconhecimento enquanto método fundador de um conceito também ele fundador. Não critico, contudo, todos os esforços de inovação, tanto teorética quanto pragmática, relativamente ao mais puro método original. A evolução constitui um caracter especificamente humano, e de tal forma o é, que é raro um método não brotar numa nova linha mais ou menos independente, mais ou menos autónoma, de métodos-filhos e/ou novas metodologias.

Direi, contudo, que o conceito de trabalho postural com base no alongamento global das estruturas miofasciais [organizadas em cadeias] com vista à reestruturação morfológica caracteriza a totalidade dos métodos de linha mézièrista, pelo menos aqueles que se relacionam mais com a nossa profissão.

É, igualmente, preciso entender que a base científica dos métodos em análise é real, sendo que os estudos que envolvem a electromiografia de Jacobson não deixam margem para dúvidas de que a actividade tónica dos músculos de natureza postural é mais persistente e menos "moldável" que a actividade tónica dos músculos de natureza fásica. 0 mesmo será dizer que a diferenciação teorética da musculatura humana em dois grandes tipos - músculos tónicos/ /posturais e músculos fásicos/ /dinâmicos - essencial para a prescrição metodológica dos métodos da linha de Mézières, é já considerada mais "facto" que "teoria", o que releva de uma grande importância para a consubstanciação conceptual dos métodos de trabaIho em Mézières. Claro que não é despiciendo o argumento - utilizado por tantos - de que o facto de existirem músculos de natureza postural não obriga à utilização de uma ginástica do tipo "estática". Ora, penso que esta questão começa a ganhar novos contornos científicos na actualidade, sendo que tem sido inalienavelmente de- 
monstrado que os músculos de natureza "tónica" são mais "sensiveis" a um trabalho também ele tónico, enquanto que os músculos de natureza "fásica" são mais "sensiveis" a um trabalho dinâmico lque os diferentes desportos de resistência e força/potência muscular tão bem demonstram]. Aliás, o conceito de ginástica "estática" e/ou "postural" é anterior à revolução de Mézières, sendo que ganhou importantes contornos científicos com a introdução e desenvolvimento do método Pilates. Não devemos esquecer, igualmente, que a primeira obra de Françoise Mézières - "La gymnastique statique" (1947) - é anterior ao princípio de observação que levaria à criação do seu método. Tudo isto demonstra que o conceito de "ginástica estática" não é derivado de Mézières e da sua revolução. $\mathbf{O}$ que realmente deriva da "revolução mézièrista" é a nova metodologia de "ginástica estática", a qual, até ali se centrava especialmente no treino de força muscular, e a partir dali, viria a centrar-se no trabalho de alongamento muscular global.

Importante será também dizer que a ideia de que a postura e/ou morfologia estaria relacionada com o estado de comprimento-tensão dos grupos musculares também não é apanágio criador de Mézières, pois, no mundo anglo-saxónico, a dita ideia já vigorava nas ginásticas mais clássicas. Aliás, durante décadas, acreditou-se que o trabalho do transverso abdominal ou dos rectos abdominais levaria à diminuição da hiperlordose lombar (já, naqueles tempos pré-Mézières, considerada como "malade postural"). Só mais tarde, Souchard ${ }^{14}$ viria a deixar bem claro - melhor que a própria Francoise Mézières que o treino, seja estático, seja dinâmico, de um qualquer músculo e/ou grupo muscular jamais poderá permitir o trabalho de "correcção" de uma deformidade, mesmo que seja funcional. $\mathbf{O}$ autor associa isso ao facto de não existir, no nosso corpo, um sistema muscular de "antagonismo puro", ou seja, a acção de determinados músculos não poderá contrariar completamente a acção de outros conjuntos musculares. Eu acrescentaria que, sendo o músculo transverso abdominal um músculo de inserção posterior lombar e anterior abdominal, ele jamais poderia ter o efeito de "deslordosar" a coluna Laliás, os mézièristas mais clássicos até acreditam que o trabalho do transverso abdominal tem um efeito lordosante e que, como tal, deve ser evitado]. Quanto aos músculos flexores dinâmicos do tronco, sendo dinâmicos nunca poderiam contrariar a acção de uma musculatura estática (posterior). Este é um bom argumento para tantos e tantos desportistas e terapeutas que acreditam que o treino dos músculos anteriores dinâmicos do tronco poderá fazer com que aumente a cifose dorsal. Como poderá aumentar a cifose dorsal por esse mecanismo, ou seja, como poderá constituir-se determinado design postural se estamos a falar de músculos de natureza dinâmica e não estática/postural?... Portanto, até aqui já citei uma série de mitos e as contradições existentes nos mesmos. Mas não fiquemos por aqui. Vamos analisar a ideia - clássica e hegemónica - de que o trabalho de "correcção postural" carece de "fortalecimento muscular". Ora, o que a experiência dos mézièristas tem demonstrado é que o fortalecimento muscular, mesmo que somente dirigido à musculatura fásica (o que é, aliás, impossível, pois não há forma de isolar completamente o trabalho da musculatura dinâmica relativamente à musculatura postural), tem por resultado o aumento do tónus da musculatura de natureza postural. Ora, é esse mesmo exagero tónico que se pretende inibir com o trabalho de "reeducação postural”. Portanto, por exemplo, o trabalho de fortalecimento dos extensores do tronco, com vista à correcção de uma hipercifose dorsal, é cem por cento irracional. E isto por várias razões. Primeiro que tudo, como se pode fortalecer músculos essencialmente tónicos (músculos extensores do tronco e musculatura adutora das omoplatas] com exercícios de fortalecimento dinâmico? Não é muito lógico, pelas razões já apresentadas. Mas, ainda assim, visto que dissemos que o trabalho dos músculos fásicos comportaria o trabalho co-sinérgico dos músculos posturais, ainda podemos pensar na possibilidade de exercícios de fortalecimento abdominal e de fortalecimento dos extensores do tronco poder ter como resultado o encurtamento dos músculos extensores. A experiência tem demonstrado que, geralmente, esse trabalho de força irá somente levar à criação de uma nova deformidade. Ou seja, a correcção da cifose, ou não é simplesmente conseguida, ou então, é conseguida à custa do encurtamento da musculatura extensora, ou seja, à custa de uma nova deformidade (com todas as consequências sintomáticas que tal acarretará). 0 trabalho de força muscular, pura e simplesmente, não é correctivo, pois tem sempre como consequência a criação de tensão numa musculatura de natureza já por si hipertónica. Aqui surgem muitas questões. Uma delas consiste no facto de a maioria 
dos atletas possuir um semblante de "endireitamento" do tronco, belo e atractivo. Ora, esse mesmo "endireitamento" do tronco constitui, a meu ver, algo comparável ao açúcar da alimentação: é belo, sabe bem, tem bom aspecto (pois já foi útil em tempos passados], mas faz mal (pois já não se adequa às necessidades do Homem presente). Os atletas, pelo facto de possuírem intensa actividade física, desenvolvem muita tensão nos extensores do tronco. Isto acontece, claro está, porque todo o trabalho de força muscular - no qual é exímio o conjunto de desportos contemporâneos - irá criar a hegemonia de tensão da musculatura postural, ou seja, o trabalho desportivo irá super-solicitar o trabalho postural. Isto leva a que os extensores do tronco da maioria dos atletas fiquem demasiadamente encurtados, dando-lhes uma aparência de "direitos". Ou seja, a grande maioria dos atletas possui o tal aspecto hegemonicamente belo, à custa de uma deformidade (de retracção muscular] em rectificação ou lordose dorsal. Talvez isto explique que estes mesmos atletas "direitinhos" sejam altamente vulneráveis a dorsalgias e cervicalgias, assim como ao aparecimento de hérnias discais.

Por tudo o que fica dito, e por muito mais, posso e devo dizer que o "endireitamento postural" constitui uma ideia supramente mitificada. Não só a "bela forma" ou "postura correcta" não consiste numa "postura direita" (ao contrário do que quase toda a gente acredita, incluindo especialistas da área], como essa tal "postura direita" constitui um erro postural inacreditavelmente dominante. Se há coisa que os mézièristas demonstraram, sem margem para dúvidas, é que a ideia de que devemos manter uma "postura direita" e de que toda a nossa higiene postural se relaciona com o "estar direito" constitui um mero e estulto mito. Tendo em conta a natureza funcional da cadeia muscular posterior, a postura "correcta" consiste, na realidade, em toda a postura que permita o alongamento muscular posterior e o trabalho de inibição tónica das hegemonias musculares prevalecentes. Assim sendo, é bastante comum os mézièristas recomendarem aos seus doentes que estes se sentem com a lombar bem apoiada, se não cifosada. Mais tarde, Souchard, temendo o nível de contra-intuição presente nesta ideia, viria a trair os princípios de higiene postural mézièrista, preferindo, muitas vezes, a colocação da coluna lombar neutra. Sugiro a observação das figuras anteriormente demonstradas (compare-se a posição da coluna lombar nas diversas posturas Mézières vs. Souchard). Diria que o treino de correcção de uma hiperlordose somente poderá ser conseguido com o trabalho de ablação total da curvatura, o que corresponde não propriamente à inversão da curvatura [como muitos críticos de Mézières têm sugerido), mas sim à eliminação de qualquer nível de lordose, mesmo a funcional cou seja, consiste, mais uma vez, no princípio mais genuinamente mézièrista, a deslordose). Mas voltando às questões da "higiene postural", talvez seja pertinente dizer que, para os mézièristas, a postura "ideal" consiste na postura do "cocheiro" (estou a referir-me verdadeiramente ao "curvado" cocheiro]. Todo o trabalho de "endireitamento" somente irá criar uma hiper-solicitação do trabalho muscular da cadeia muscular posterior, o que, a longo prazo irá traduzir-se na fadiga e consequente "encurvamento". Ou seja, o trabalho de força da musculatura extensora irá, pela natureza de trabalho neuromuscular desta musculatura, criar um nível de fadiga tal, que a pessoa irá, lentamente tender para a cifose. Quer isto dizer que, ao contrário do que a intuição nos poderia fazer pensar, o trabalho dos extensores do tronco ainda vai aumentar mais a cifose la não ser claro que, como acontece com os desportistas, se crie a retracção hegemónica da musculatura entre as omoplatas, o que levaria a um "endireitamento patológico"]. É preciso entender que a capacidade de "endireitamento postural" está dependente do bom funcionamento tónico da musculatura extensora postural, o que, tendo em conta o que sabemos do funcionamento deste tipo de músculos, significa a capacidade de manter a contracção por períodos prolongados de tempo sem criar fadiga. Ou seja, o "endireitamento postural" será tanto maior quanto mais flexiveis forem os músculos posturais; a capacidade para manter a contracção está fortemente dependente da capacidade elástica da musculatura. Significa, então, que, quanto mais flexível for a musculatura postural, mais capacidade tem a mesma de gerar uma contracção anti-gravítica persistente. Aliás, as minhas observações têm-me dado a entender que a facilidade para nos mantermos "direitos" advém do comprimento da cadeia muscular posterior, ou seja, advém da flexibilidade da musculatura posterior. E isto não é novidade alguma, pois, qualquer bom observador poderá facilmente ver a diferença na forma como uma pessoa flexível se senta, relativamente a uma pessoa menos flexível. 
Compare-se, por exemplo, as senhoras com os senhores. Quem tem, geralmente, maior capacidade para manter uma postura sentada direita (com pernas esticadas]? As senhoras, que são mais flexíveis? Ou os senhores, que são mais "fortes"?... 0 princípio mais primacial de observação leva-nos a verificar que são as senhoras as que possuem mais facilidade em obter determinadas posturas, o que advém da sua maior flexibilidade mio-fascial.

A ideia de que as lombalgias estão associadas à falta de um "reforço muscular" é, portanto, falaciosa. E a todos aqueles que poderão apresentar linhas de estudos que demonstram essa relação, eu apresento linhas de estudos que contradizem essa mesma relação, assim como muitas outras linhas de estudos que relacionam flexibilidade, morfologia, mobilidade, e muitos outros factores, com a presença/ /ausência de dor. Diria que ainda estamos muito longe de atingir uma plena maturidade metodológica que permita atribuir credibilidade suficiente às diversas linhas de estudos existentes. 0 mesmo será dizer que, atendendo ao que tenho visto em tantos e tantos artigos, pouco se sabe verdadeiramente, em termos científicos, sobre a relação entre os diversos factores biomorfológicos e a raquialgia. Prefiro, pessoalmente, mergulhar na natureza apodíctica das bases conceptuais de um método revolucionário como o método Mézières. E é no seio dessa mesma natureza que o princípio revolucionário de que as deformidades posturais e as raquialgias são devidas aos excessos musculares e/ou tónicos e não à fraqueza toma aspecto de uma verdadeira "lei" de estudo etiopatogénico e de intervenção terapêutica.
Importante será acrescentar que, na actualidade, principalmente no campo teorético da "Reconstrução Postural", parece que tudo o que dissemos sobre excessos musculares está relacionado mais com o "tónus em si mesmo" do que com o "comprimento muscular". Assim sendo, as deformidades e dores ósteo-musculares advêm sobretudo da incapacidade que as estruturas musculares têm para criar "pontos" de modificabilidade tónica.

Ora, neste ponto, importa referenciar novamente o paradigma de Bricot. Ou seja, se vamos passar a valorizar mais o campo "neurológico" do trabalho postural, não podemos deixar de sublinhar a importância do trabalho terapêutico com base no treino proprioceptivo e de equilíbrio e no relaxamento psicofísico. Aliás, se a "postura" depende fortemente de uma capacidade de "controlo neurológico central", que, sendo essencialmente subcortical, é de natureza fundamentalmente inconsciente, então devemos, tal como o fez Bernard Bricot valorizar o papel do trabalho "neurológico", percebendo, de uma vez por todas, que a ordem "consciente" e "voluntária" para "endireitar" as costas de nada serve. Ora, se o mecanismo de controlo postural é inconsciente de que serve mandar alguém "endireitar-se"?... A experiência tem demonstrado que as metodologias que fazem uso de estratégias de controlo consciente da posição corporal são ineficazes. Diria que certas metodologias de "actividade física" que privilegiam o "global" ao invés do "analítico", e o "motor" ao invés do "físico", como a dança, a psicomotricidade, o relaxamento, as artes marciais e todas as actividades que façam uso das capacidades de equilibração e de coorde- nação neuromotora, poderão ter mais eco no trabalho de "reeducação postural". Portanto, para além das metodologias mais fisicalistas, todas as outras mais psiconeurológicas possuem uma importância provavelmente fulcral.

Portanto, temos que uma intervenção a nível reumatológico, na presença da "deformidade postural" e ou de sintomas raquidianos, passa por um trabalho necessariamente ecléctico, centrado fundamentalmente no paradigma Mézières, o que inclui também a sua componente psicofísica e de integração neuro-sensorial.

Como vimos, para o paradigma em análise, todas as deformidades posturais possuem origem em "excessos" da musculatura essencialmente posterior. As lordoses são a origem. As escolioses estão sempre correlacionadas com um excesso muscular da musculatura lordosante los mesmos músculos paravertebrais que estão envolvidos na flexão lateral, e eventualmente, na rotação dos corpos vertebrais da coluna, são também os músculos mais poderosamente envolvidos na "lordose"). E as cifoses resultam também de uma compensação lordótica, seja devido à acção de contrariação "directa" da lordose, seja devido à acção do diafragma, seja devido à acção dos músculos rotadores internos, ou da acção mais "indirecta" das cadeias musculares anteriores (sempre relacionadas com a "posterior", relação mediada pelo diafragma].

Vimos, também, já bastante atrás, que a o conceito de postura "normal" e de postura "anormal" não é correcto, visto que ninguém possui uma postura perfeita. Portanto, no campo "postural", raramente alguém é isento de hegemonias musculares, raramente alguém possui 
uma postura dita "normal", e raramente alguém possui características "perfeitas" de flexibilidade muscular. Ora, o que tudo isto vai implicar é que a linha teorética que divide "saúde" de "deformidade" é extremamente espúria, se é que chega a existir. Ou seja, todos nós somos "doentes posturais" em potência e, portanto, tudo o que fica dito para as pessoas com deformidades posturais relevantes, mantêm-se oportuno para a totalidade das pessoas, pois todos nós possuímos algum grau de "deformidade postural". O mesmo será dizer que, em termos analíticos, todos nós possuímos determinada idiossincrasia, e somos tanto mais saudáveis quanto melhores as condições de bom alinhamento e a proximidade à "bela forma". E todos devemos tender para a "bela forma". E tudo deveríamos fazer para criar tal tendência, a qual não deixa de se aproximar do conceito kantiano de "perfectibilidade" humana.

Por exemplo, o mecanismo patológico da artrose está intimamente relacionado com a "postura". Os médicos tendem a relacionar a "artrose", ou qualquer outro processo degenerativo, com a osteoporose e outros factores de desgaste articular. Mas, eu diria que, se a postura fosse perfeita, se o alinhamento fosse perfeito, nunca teriam estado presentes factores relevantes de desgaste articular. Ou seja, a "perfectibilidade" é condição do bom funcionamento articular. E essa "perfectibilidade" está dependente da "forma" e, portanto, dos factores miofasciais e neuromusculares que com ela se relacionam. Se a pessoa possuir algo perto da "bela forma", e não vier a ter alguma condição reumatológica e/ou orto-traumatológica relevante que modifique as condições de alinhamento articular, é pouco provável que venha a sofrer de qualquer tipo de condição degenerativa. Acrescentaria que estas mesmas pessoas também são aquelas que podem praticar actividades como "andar", "correr" ou "saltar" com a menor probabilidade de virem a criar problemas articulares decorrentes de deformidades la não ser que o excesso de prática desportiva modifique o panorama tónico-muscular presente). Por outro lado, o que dizer da "saúde" de alguém que possua um certo nível de desalinhamento e/ou deformidade (mesmo que não notória)?... Será que as pessoas com um nível mínimo de deformidade poderão praticar actividades físicas com o mesmo à-vontade que as pessoas que possuem grande nível de "bela forma"?...

Aquilo que tenho defendido é que não. Ou seja, deverá haver, para a maioria das pessoas, uma diminuição cabal da tendência para a prática de desportos como os de carácter assimétrico e as actividades de fitness, pois, estando estas actividades grosseiramente centradas no trabalho da "força muscular", acabarão por funcionar como uma porta de entrada para a criação de tensão muscular e consequente deformidade. Atenção: não pretendo negar a evidência que tantos estudos (ditos funcionais) têm lançado sobre determinadas vantagens que advêm da prática desportiva. Falo só em termos "posturais", "estruturais", "morfológicos", ou, mais globalmente, "músculo-esqueléticos". E o que defendo é que, ao contrário do que muitos preconizam, a actividade desportiva, principalmente as novas modalidades do fitness, potenciam o exacerbar de hegemonias musculares que se queriam refreadas.
E isto é tanto mais verdade quanto maior a tendência que o indivíduo possui para a tensão muscular e a retracção mio-fascial.

Em particular, certos desportos, como a musculação, constituem, provavelmente, um factor importante de criação de desequilíbrios musculares relevantes. Analisem-se as "posturas" dos culturistas e retirem-se as necessárias conclusões...

Já Françoise Mézières, no seu "Originalité de la Méthode Mézières"7, dizia que «a la différence de toutes les autres méthodes, ma méthode: 1 ㅇ ne s'adresse qu'à élasticité musculaire; 2 ne fait jamais de muscu-

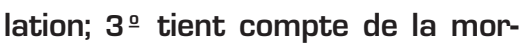
phologie normale; $4^{\circ}$ n'exerce jamais l'inspiration; 50 ne fait jamais d'exercice analytique; $6 \circ$ ne fait jamais d'exercice perpendiculaire à l'axe rachidien; 7 ㅇ ne s'adresse qu'au physique.» $E$ quem a conheceu, diz que Mézières não simpatizava sequer com o Yoga. 0 que é perfeitamente compreensível, pois, estando repleto de posturas em (hiper)lordose, e de fortalecimento dos extensores do tronco, torna-se extremamente anti-mézièrista. Portanto, depois de percebermos que tanto o método Mézières como os métodos neo-mézièristas não gostam do trabalho de força, aqui está este autor a generalizar o conceito à totalidade dos praticantes de actividade física. A actividade física, principalmente a actividade intensa e/ou com fins competitivos, constitui uma porta de entrada para a "deformidade". E o atleta inteligente é, indiscutivelmente, aquele que treina a sua flexibilidade!...

Ora, a solução não passa, portanto, pela evicção da actividade desportiva, apesar de em muitos casos tal ser recomendável. Passa, sobretudo, pela realização de actividades 
ligeiras, suaves, com carácter essencialmente cardiovascular. E essas actividades deverão ser acondicionadas a toda uma nova metodologia de trabalho físico.

Ou seja, pretendo dizer que actividades que fazem uso "directo" da força da cadeia muscular posterior, como a natação, a musculação e o Yoga, deveriam ser proibidas aos padecedores de raquialgias. Jamais deveriam ser recomendadas, que é o que uma miríade de profissionais de saúde ainda faz. E essas mesmas actividades são, a meu ver, desaconselhadas a qualquer pessoa, a não ser àquelas que possuam condições de flexibilidade excelentes.

Outras actividades, como a maioria dos desportos de carácter assimétrico, e a quase totalidade de práticas do fitness, possuem igualmente uma incomensurável irracionalidade, pelos mesmos motivos que já apresentei.

Por outro lado, certas actividades cardiovasculares, como o simples "andar" podem ser muito benéficas para a saúde, mas mesmo estas deverão ser inseridas num novo plano de treino físico. Pois, até mesmo esse "andar" poderá apresentar malefícios num indivíduo que apresente deformidade. Não será assim tão estranho pensar no que acontece a um joelho excessivamente valgo ou excessivamente varo, após horas de marcha ou mesmo meia hora de corrida... Por outro lado, o jogo de forças articulares deletérias poderá ser beneficiado de um trabalho preliminar de alongamento. Esse mesmo plano ou metodologia é diferente da tradicional e consiste na realização, pela ordem que vou apresentar, do seguinte leque de actividades: 1 relaxamento; 2 alongamento

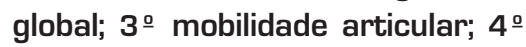
força do core e trabalho facilitado das extremidades, 5 alongamento global e 6 o relaxamento. Portanto, inicialmente, têm de ser criadas condições de relaxamento das estruturas miofasciais, através dos métodos de relaxamento. Somente este relaxamento inicial irá facilitar o alongamento. Só depois deverá ser realizado o alongamento. Este deve, tal como já foi dito (anteriormente), ser feito a frio, global e progressivamente por períodos prolongados de tempo. 0 relaxamento e $\mathrm{o}$ alongamento libertam as estruturas articulares. Só nesta altura deverão ser realizadas as actividades de mobilidade lactividades cardiovasculares, ginásticas de mobilidade), as quais deverão ser suaves. E só no fim de todas as estruturas estarem adequadamente "libertas" de tensão, é que se pode pensar na realização do treino de força. Este deve privilegiar o trabalho do "centro do corpo", como no Pilates, e o trabalho "facilitado" das estruturas à periferia. De modo a não se acabar o trabaIho físico em posição de encurtamento, deve-se voltar a alongar globalmente (com os cuidados necessários ao alongamento a quente] e acabar com o relaxamento.

Ora, é indubitável que este novo "esquema" de trabalho físico implicaria uma série de mudanças. Neste novo esquema, a saúde passaria para primeiro plano, enquanto que a "estética", a "moda" e toda a efemeridade patente no fitness passariam para segundo plano.

Este tipo de metodologia também obrigaria a que os treinadores e professores passassem a dispor de um conhecimento mais alargado da "teoria das cadeias musculares", das novas formas de alongamento, e das necessárias implicações metodológicas do mesmo baseadas no conceito de Mézières. E também implicaria o erradicar do mito do "endireitamento postural", já anteriormente aludido.

0 método Mézières e os métodos neo-mézièristas lançam-nos uma série de pistas relativamente a um novo conceito de "cultura física", menos centrada na performance e na robustez muscular e mais centrada na função com base na "bela forma".

\section{$-1$ \\ REFERÊNCIAS}

1. Tribastone, 2001 - livro principal.

2. Bricot.

3. Richardson et al - livro da estabilização.

4. Psicomotricidade

5. Relaxamento.

6. Mézières F. L'homéopathie française. Ed. G. DOIN. 1972; 4 - 195.

7. Mézières F. Mézières F. Originalité de la méthode mézières. Paris: Maloine, 1984.

8. Mézières F. Révolution en gymnastique orthopédique.

9. Turlin P. Françoise Mézières sort du silence. Kiné Actualité 1990 (332): 6-7.

10.BertheratT. Le corps a ses raisons.

11. Bertherat.

12. Bertherat.

13. Bertherat.

14. Souchard Ph-E Le champs clos

- Bases de la Rééducation Posturale Globale

15. Souchard Ph-E Les scolioses Traitement kinésithérapique et orthopédique.

16. Souchard Ph-E Le stretching global actif

17. Busquet.

18. Busquet. 
19. Godelieve Denys-Struyf.

20. Nisand M. Le traitement des algies vertébrales par la Reconstruction Posturale. La lettre du médecin rééducateur 1997.

21.Publication périodique de l'ANMSR (Association Nationale des Médecins spécialistes en Rééducation].

22. Nisand M. Formation continue: Premier stage de Reconstruction Posturale à Genève. Le Magazine 1997; 97.

23. Nisand M. La Reconstruction Posturale: une physiothérapie normative de la forme. Mains Libres, la revue Romande de physiothérapie 1997.

24. Jesel M. Reconstruction Posturale. Concept; traitement des dysmorphismes et des algies du tronc et des membres. Kinésithérapie Scientifique 1999; 387.

25. Jesel M, Callens C, Nisand M. Rééducation fonctionnelle dans les cervicalgies communes selon la méthode de reconstruction posturale: concept et aspect technique. Kinésithérapie Scientifique 2001; 417. 26. Nisand M, Callens C, Jesel M. À propos de certains dysmorphismes du pied: identification et correction par la Reconstruction Posturale ${ }^{\circledR}$. KINÉSITHÉRAPIE, les annales 2002; 10: 37-42.

27. Callens C. Entre le tout renforcement et le tout étirement, existe-t-il une autre voie?. 11ème Symposium Roman de Physiothérapie les 5 et 6 novembre 2004: "Les Chaînes Déchaînées” Lausanne-Suisse. Mains Libres, la revue Romande de Physiothérapie novembre 2004.

28. Nisand M. La Reconstruction Posturale $\AA$, déviance ou évolution? 11 ème Symposium Roman de Physiothérapie les 5 et 6 novembre 2004: "Les Chaînes Déchaînées" Lausanne-Suisse. Mains Libres, la revue Romande de Physiothérapie novembre 2004.

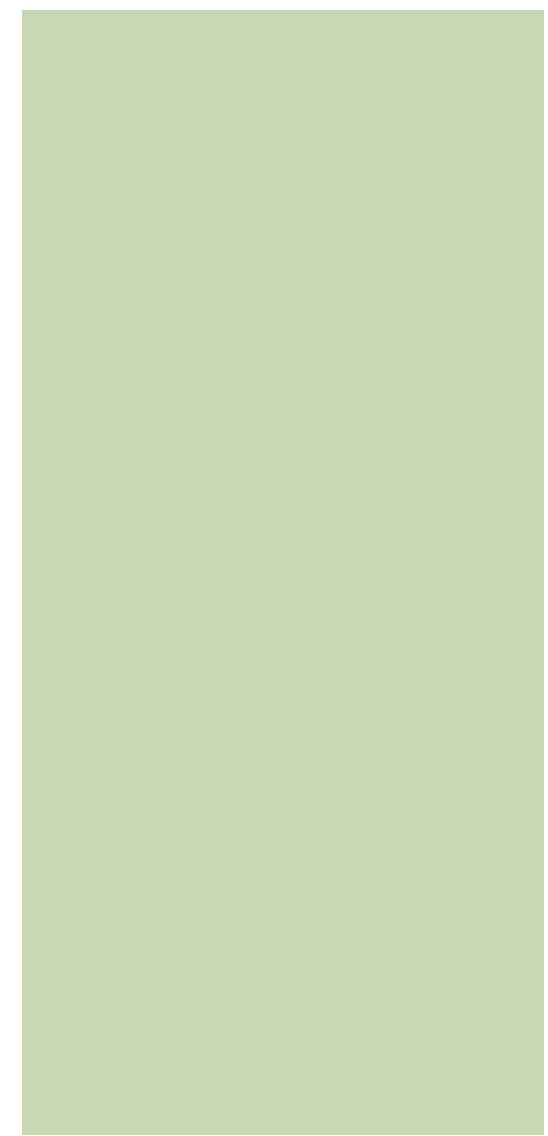

